Prepared in cooperation with the Louisiana Department of Transportation and Development

\title{
Water Resources of Claiborne Parish, Louisiana
}

\section{Introduction}

This fact sheet presents a brief overview of groundwater and surface-water resources in Claiborne Parish, Louisiana (fig. 1 ). Information on the availability, use, and quality of water from groundwater and surface-water sources in the parish are discussed. Previously published reports and data stored in the U.S. Geological Survey's National Water Information System are the primary sources of this information.

In 2010, about 2.60 million gallons per day (Mgal/d) of water were withdrawn in Claiborne Parish, Louisiana, including about $2.42 \mathrm{Mgal} / \mathrm{d}$ from groundwater sources and $0.18 \mathrm{Mgal} / \mathrm{d}$ from surface-water sources ${ }^{1}$ (table 1). Publicsupply use accounted for about 84 percent of the total water withdrawn. Other categories of use included industrial, rural domestic, livestock, and general irrigation (table 2). Water-use data collected at 5-year intervals from 1960 to 2010 indicated that total water withdrawals in the parish have ranged from about 2.6 to $3.9 \mathrm{Mgal} / \mathrm{d}$ (fig. 2).

${ }^{1}$ Tabulation of numbers in text and tables may result in different totals because of rounding; nonrounded numbers are used for calculation of totals.

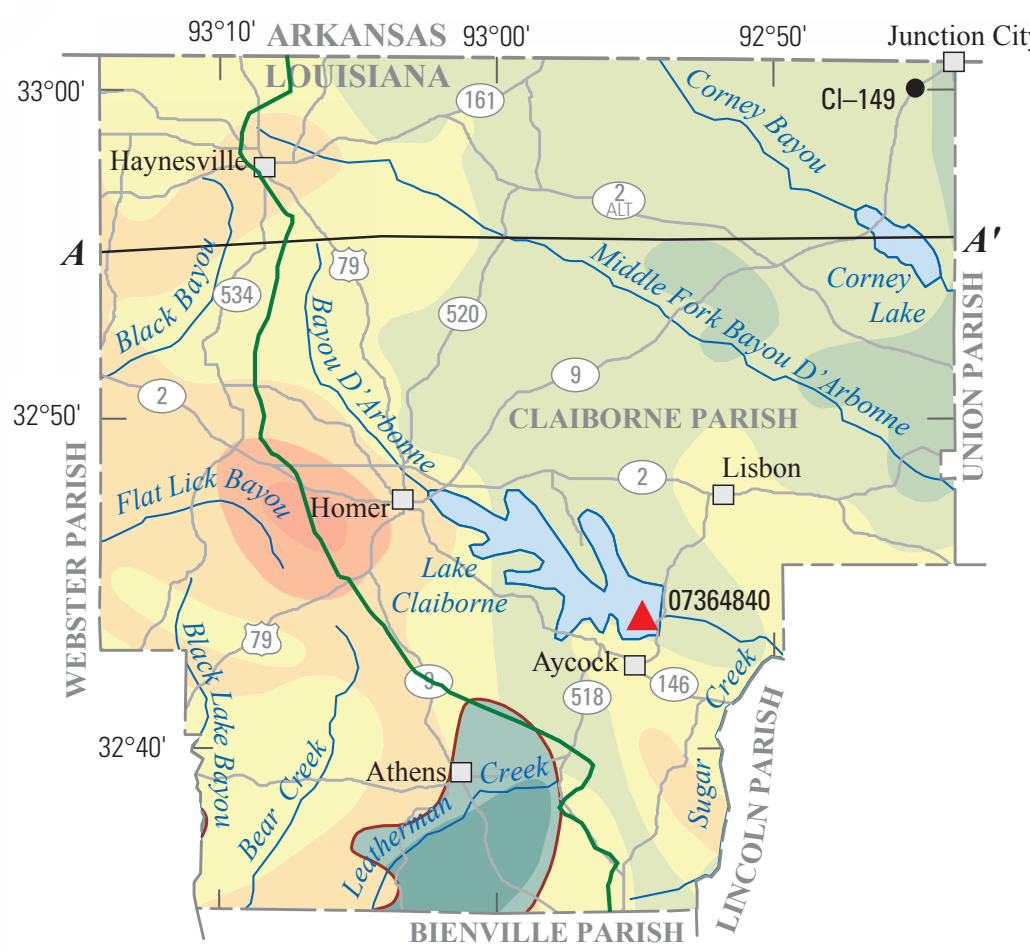

Base modified from U.S Geological Survey digital data Universal Transverse Mercator, zone 15 North American Datum of 1983
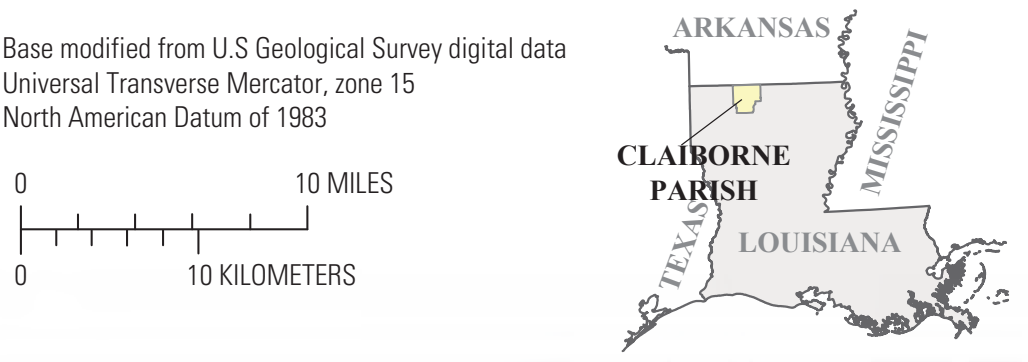

Figure 1. Location of study area, Claiborne Parish, Louisiana.

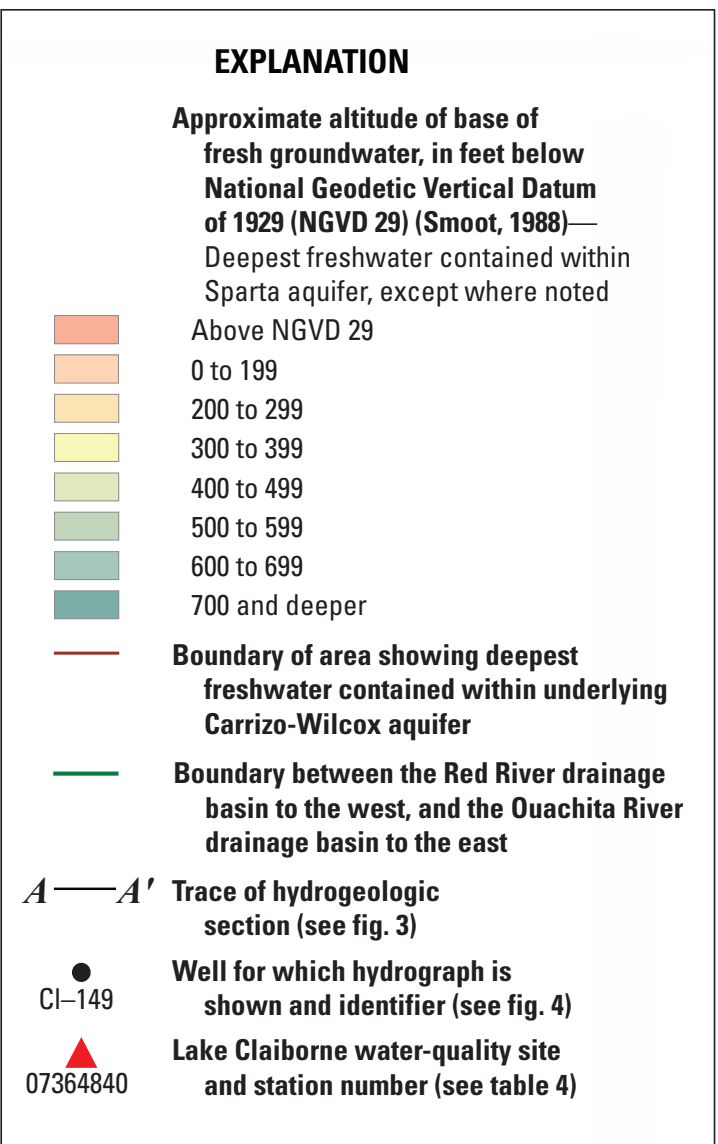


Table 1. Water withdrawals, in million gallons per day, by source in Claiborne Parish, Louisiana, 2010 (modified from Sargent, 2011)

\begin{tabular}{lcc}
\hline $\begin{array}{c}\text { Aquifer, confining unit, } \\
\text { or surface-water body }\end{array}$ & Groundwater & Surface water \\
\hline Cockfield aquifer & 0.01 & \\
Cook Mountain aquifer & 0.04 & \\
Sparta aquifer & 2.38 & 0.18 \\
Miscellaneous streams & & 0.18 \\
\cline { 2 - 3 } Total & 2.42 & \\
\hline
\end{tabular}

Table 2. Water withdrawals, in million gallons per day, by category in Claiborne Parish, Louisiana, 2010 (modified from Sargent, 2011)

\begin{tabular}{lccc}
\hline \multicolumn{1}{c}{ Category } & Groundwater & Surface water & Total \\
\hline Public supply & 2.19 & 0.00 & 2.19 \\
Industrial & 0.00 & 0.15 & 0.15 \\
Rural domestic & 0.17 & 0.00 & 0.17 \\
Livestock & 0.03 & 0.03 & 0.06 \\
General irrigation & 0.04 & 0.00 & 0.04 \\
\cline { 2 - 4 } Total & 2.42 & 0.18 & 2.60 \\
\hline
\end{tabular}

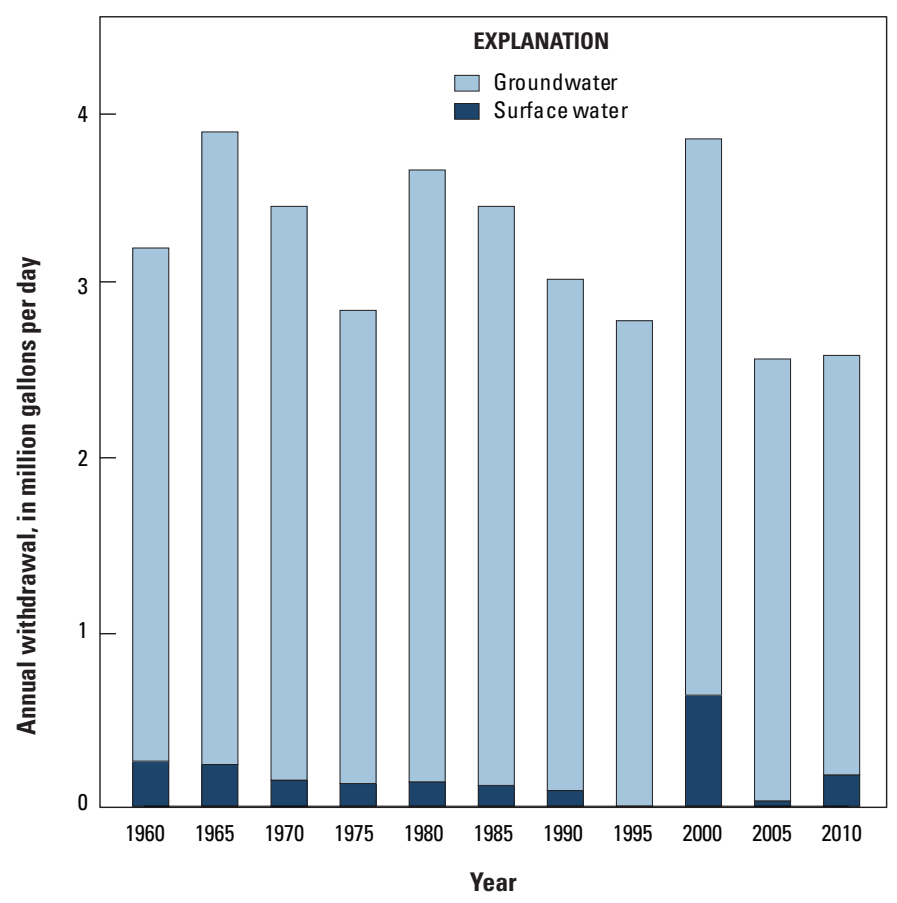

Figure 2. Water withdrawals in Claiborne Parish, Louisiana, $1960-2010$.

\section{Groundwater Resources}

The primary fresh (water with a chloride concentration of 250 milligrams per liter [mg/L] or less) groundwater sources in Claiborne Parish, from near surface to deepest, are the Cockfield aquifer, Cook Mountain aquifer, and Sparta aquifer (fig. 3). The underlying Carrizo-Wilcox aquifer contains saltwater throughout Claiborne Parish except for an irregular area extending from north of Athens, southward to the Claiborne-Bienville Parish line (fig. 1) (Ryals, 1984). According to State well-registration records, there were no active water-supply wells screened in the freshwater area of the Carrizo-Wilcox aquifer in Claiborne Parish in 2009 and there were no reported withdrawals from the aquifer in that area for 2010.

Fresh groundwater is generally available throughout the parish. The base of fresh groundwater within Claiborne Parish is located at depths generally ranging from 0 feet (ft) to $700 \mathrm{ft}$ below the National Geodetic Vertical Datum of 1929 (NGVD 29) (fig. 1) (Smoot, 1988). Recharge to aquifers in Claiborne Parish is from precipitation, leakage from adjacent aquifers and confining units, and seasonal input from streams. Discharge from the aquifers is by natural flow into streams, leakage into adjacent aquifers and confining units, and withdrawals from wells.

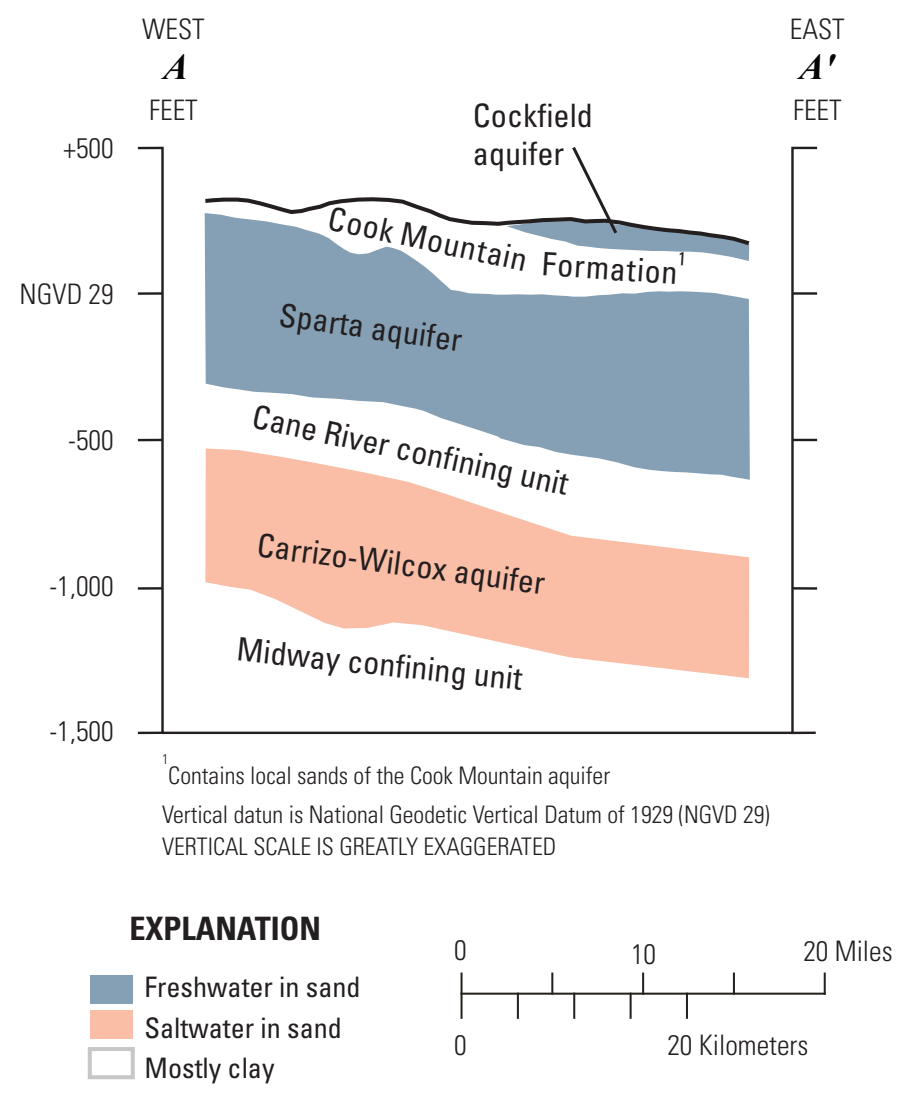

Figure 3. Generalized west-to-east hydrogeologic section showing aquifer and confining-unit intervals through Claiborne Parish, Louisiana (modified from Ryals, 1984). Individual sand and clay layers not shown. Trace of section shown on figure 1. 
State well-registration records listed 255 active water wells (public supply, industrial, domestic, irrigation, or power generation) in Claiborne Parish in 2009, including 99 domestic, 62 public supply, 47 industrial, and 47 irrigation wells. In 2010, groundwater withdrawals for various uses included public supply, rural domestic, livestock, and general irrigation (table 2).

\section{Cockfield Aquifer}

In Claiborne Parish, the Cockfield aquifer is composed of very fine to fine sands (Stuart and others, 1994). The aquifer is present and outcrops at land surface in much of the northern half of the parish but is absent in stream valleys. The aquifer is also present in small, scattered areas in south-central Claiborne Parish (Snead and McCulloh, 1984). The thickness of the Cockfield aquifer in Claiborne Parish generally ranges from 0 to $200 \mathrm{ft}$, and the base of the aquifer generally is greater than $100 \mathrm{ft}$ above NGVD 29 (Ryals, 1984). The principal source of recharge to the Cockfield aquifer is precipitation.

State well-registration records listed 13 active wells screened in the Cockfield aquifer in Claiborne Parish in 2009, including 11 domestic and 2 irrigation wells. Depths of these wells ranged from 16 to $81 \mathrm{ft}$ below land surface, with a median depth of $45 \mathrm{ft}$. State well-registration records for Claiborne Parish indicated that yields from wells screened in the Cockfield aquifer range from 3 to 50 gallons per minute (gal/min). In 2010, withdrawals from the aquifer in Claiborne Parish were about $0.01 \mathrm{Mgal} / \mathrm{d}$ (table 1).

\section{Cook Mountain Aquifer}

The Cook Mountain aquifer is present as local sands within the Cook Mountain Formation, which underlies the Cockfield aquifer in northern Claiborne Parish, but outcrops or subcrops in stream valleys in the northern half of the parish and throughout most of the southern half of the parish where the Cockfield aquifer is absent (fig. 3). The formation is generally composed of clay but locally contains sands, which form the aquifer and are sources of freshwater for wells (Hosman, 1978). The full thickness of the formation ranges from 0 to $200 \mathrm{ft}$ in Claiborne Parish (Ryals, 1984).

State well-registration records listed 24 active water wells screened in the Cook Mountain aquifer in Claiborne Parish in 2009, including 11 domestic, 7 irrigation, 3 public-supply, and 3 livestock wells. Depths of these wells ranged from 15 to $248 \mathrm{ft}$ below land surface, with a median depth of $140 \mathrm{ft}$. State well-registration records for Claiborne Parish indicated that yields from wells screened in the unit range from 3 to $40 \mathrm{gal} /$ min. In 2010, withdrawals from the Cook Mountain aquifer in Claiborne Parish were about 0.04 Mgal/d (table 1).

\section{Sparta Aquifer}

The largest source of fresh groundwater in Claiborne Parish is the Sparta aquifer, which underlies the Cook Mountain Formation. The Sparta aquifer is present throughout Claiborne Parish and consists of 200 to $800 \mathrm{ft}$ (Ryals, 1984) of sand, silty sand, and silty shale with occasional lignites and lignitic shales (Martin and others, 1954). Sand composes about 30 to 70 percent of the total thickness of the Sparta aquifer (Hosman, 1978), and the total sand thickness of the aquifer ranges from about 400 to $600 \mathrm{ft}$ in Claiborne Parish (Ryals, 1984). The Sparta aquifer dips gently to the east and northeast in Claiborne Parish (Brantly and others, 2002). The base of the aquifer is generally about $300 \mathrm{ft}$ below NGVD 29 along the western parish line and deepens to the east and northeast to depths of 450 to $600 \mathrm{ft}$ below NGVD 29 along the eastern parish line (fig. 3). The base of the aquifer is shallowest, about $100 \mathrm{ft}$ above NGVD 29, a few miles west of the town of Homer (Brantly and others, 2002). The aquifer is recharged by precipitation, and groundwater flow in Claiborne Parish is generally to the northeast (Brantly and others, 2002).

In 2007, water levels in the Sparta aquifer in Claiborne Parish ranged from about $160 \mathrm{ft}$ above NGVD 29 in the southwest corner of the parish to nearly $60 \mathrm{ft}$ below NGVD 29 in the northeast corner of the parish (Schrader, 2008). Regionally, water levels throughout much of the aquifer have declined steadily since the early 1920s when water withdrawals for industrial purposes began (Brantly and others, 2002). In 2004, withdrawals from the Sparta aquifer in Arkansas, north of Claiborne Parish, were reduced sharply through conservation efforts and the use of surface water (Freiwald and Johnson, 2008). This reduction in withdrawals has affected water levels in the Sparta aquifer in northern Claiborne Parish; water levels in well Cl-149, located near Junction City, have risen about $25 \mathrm{ft}$ from 2000 to 2010 (fig. 4). For the 10-year period 1990-99, water levels in well Cl-149 had declined at a rate of about $2 \mathrm{ft}$ per year (Tomaszewski and others, 2002).

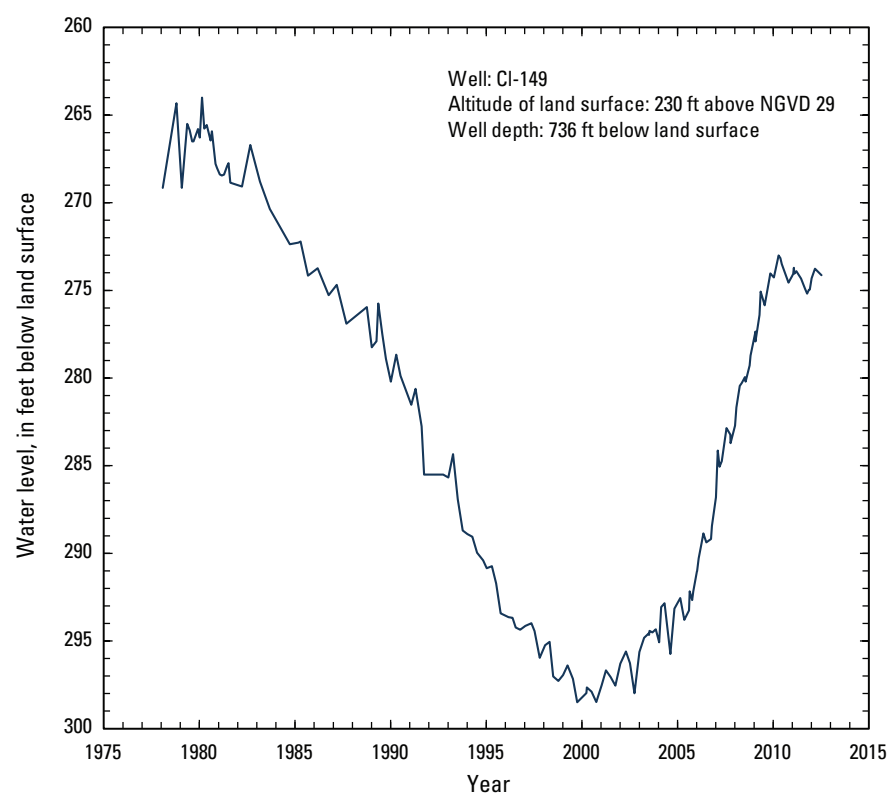

Figure 4. Water levels in well Cl-149, screened in the Sparta aquifer and located near Junction City, Louisiana (see fig. 1 for well location; U.S. Geological Survey, 2012a). Land surface is measured in feet (ft) above the National Geodetic Vertical Datum of 1929. 
State well-registration records listed 191 active wells screened in the Sparta aquifer in Claiborne Parish in 2009, including 69 domestic, 56 public-supply, 37 industrial, and 29 irrigation wells. Depths of these wells ranged from 60 to $792 \mathrm{ft}$ below land surface, with a median depth of $492 \mathrm{ft}$. State well-registration records for Claiborne Parish indicated that yields from wells screened in the Sparta aquifer range from 3 to $901 \mathrm{gal} / \mathrm{min}$. In 2010, groundwater withdrawals from the Sparta aquifer in Claiborne Parish totaled about $2.38 \mathrm{Mgal} / \mathrm{d}$ and included about 2.19 Mgal/d for public-supply, $0.13 \mathrm{Mgal} / \mathrm{d}$ for rural-domestic use, $0.03 \mathrm{Mgal} / \mathrm{d}$ for livestock, and $0.03 \mathrm{Mgal} / \mathrm{d}$ for general irrigation.

A statistical summary of selected water-quality characteristics for freshwater samples collected from 80 wells screened in the Sparta aquifer in Claiborne Parish is listed in table 3. Based on median values of constituents, freshwater from the aquifer generally is soft ${ }^{2}$ and generally does not exceed the U.S. Environmental Protection Agency's (EPA) Secondary Maximum Contaminant Levels ${ }^{3}$ (SMCLs) for drinking water for $\mathrm{pH}$, chloride, and dissolved solids. Water in some areas exceeds the SMCLs for iron, manganese, and color.

${ }^{2}$ Hardness ranges, expressed as milligrams per liter of calcium carbonate, are as follows: 0-60, soft; 61-120, moderately hard; 121-180, hard; greater than 180, very hard (Hem, 1985).

${ }^{3}$ The SMCLs are nonenforceable Federal guidelines regarding cosmetic effects (such as tooth or skin discoloration) or aesthetic effects (such as taste, odor, or color) of drinking water. At high concentrations or values, health implications as well aesthetic degradation might exist. SMCLs were established as guidelines for the states by the U.S. Environmental Protection Agency (1992).

\section{Surface-Water Resources}

In 2010, about $0.18 \mathrm{Mgal} / \mathrm{d}$ of surface water were withdrawn in Claiborne Parish, which included about $0.15 \mathrm{Mgal} / \mathrm{d}$ for industrial use and $0.03 \mathrm{Mgal} / \mathrm{d}$ for livestock (table 2). All water withdrawals came from miscellaneous streams (table 1). Notable streams in the parish include Corney Bayou, which drains the northeastern corner of the parish, Middle Fork Bayou D'Arbonne, which drains the north-central area of the parish, and Bayou D'Arbonne, which drains the central part of the parish (fig. 1). These three streams generally flow towards the southeast and are part of the Ouachita River drainage basin. Black Lake Bayou, Bear Creek, and Leatherman Creek (fig. 1) drain the southwestern corner of the parish. These three streams generally flow towards the south and are part of the Red River drainage basin (Prakken and Wright, 2009). Black Bayou and Flat Lick Bayou (fig. 1) drain western areas of the parish and are part of the Red River drainage basin.

Lake Claiborne formed after a dam on Bayou D'Arbonne was completed in 1966. The spillway crest has an elevation of $185 \mathrm{ft}$, and when full, the reservoir has a surface area of 10 square miles $\left(\mathrm{mi}^{2}\right)(6,400$ acres), an average depth of $16 \mathrm{ft}$, and a drainage area of $133 \mathrm{mi}^{2}$. Data collected in the 1960s and 1970s (table 4) indicated that water in the reservoir is generally soft, with low chloride and sulfate concentrations. During the summer months, the lake becomes stratified and the oxygen in the water near the bottom becomes depleted. This lack of oxygen allows the concentrations of hydrogen sulfide, iron, and manganese to increase to nuisance levels (Shampine, 1971).

Table 3. Summary of selected water-quality characteristics for freshwater in the Sparta aquifer in Claiborne Parish, Louisiana (U.S. Geological Survey, 2012b).

[Values are in milligrams per liter, except as noted. ${ }^{\circ} \mathrm{C}$, degrees Celsius; PCU, platinum cobalt units; $\mu \mathrm{S} / \mathrm{cm}$, microsiemens per centimeter; SU, standard units; $\mathrm{CaCO}_{3}$, calcium carbonate; $\mu \mathrm{g} / \mathrm{L}$, micrograms per liter; NA, not applicable; SMCL, Secondary Maximum Contaminant Level established by the U.S. Environmental Protection Agency (2012)]

\begin{tabular}{|c|c|c|c|c|c|c|c|c|c|}
\hline & $\begin{array}{l}\text { Temper- } \\
\text { ature }\left({ }^{\circ} \mathrm{C}\right)\end{array}$ & $\begin{array}{l}\text { Color, } \\
\text { (PCU) }\end{array}$ & $\begin{array}{c}\text { Specific } \\
\text { conductance, } \\
\text { field }(\mu \mathrm{S} / \mathrm{cm} \\
\left.\text { at } 25^{\circ} \mathrm{C}\right)\end{array}$ & $\begin{array}{l}\mathrm{pH}, \\
\text { field } \\
\text { (SU) }\end{array}$ & $\begin{array}{l}\text { Hardness } \\
\text { (as } \mathrm{CaCO}_{3} \text { ) }\end{array}$ & $\begin{array}{l}\text { Chloride, } \\
\text { filtered } \\
\text { (as CI) }\end{array}$ & $\begin{array}{c}\text { Iron, } \\
\text { filtered } \\
(\mu \mathrm{g} / \mathrm{L} \text { as Fe) }\end{array}$ & $\begin{array}{c}\text { Manga- } \\
\text { nese, } \\
\text { filtered } \\
\text { ( } \mu \mathrm{g} / \mathrm{L} \\
\text { as } \mathrm{Mn} \text { ) }\end{array}$ & $\begin{array}{c}\text { Dissolved } \\
\text { solids, } \\
\text { filtered }\end{array}$ \\
\hline \multicolumn{10}{|c|}{ Sparta aquifer (1942-2009) (80 wells) } \\
\hline Median & 22.0 & 10 & 226 & 7.6 & 19 & 11 & 250 & 10 & 171 \\
\hline 10th percentile & 21.0 & 5 & 120 & 6.6 & 4 & 4.9 & 40 & 0 & 113 \\
\hline 90th percentile & 24.0 & 40 & 506 & 8.4 & 97 & 28 & 2,100 & 100 & 308 \\
\hline Number of samples & 29 & 45 & 46 & 46 & 79 & 78 & 38 & 28 & 47 \\
\hline \multicolumn{10}{|c|}{ SMCLs } \\
\hline & NA & 15 & NA & $6.5-8.5$ & NA & 250 & 300 & 50 & 500 \\
\hline
\end{tabular}


Table 4. Selected water-quality characteristics for Lake Claiborne near Aycock, Louisiana (U.S. Geological Survey, 2012c).

[Values are in milligrams per liter, except as noted. ${ }^{\circ} \mathrm{C}$, degrees Celsius; $\mu \mathrm{S} / \mathrm{cm}$, microsiemens per centimeter; $\mathrm{SU}$, standard units; $\mu \mathrm{g} / \mathrm{L}$, micrograms per liter; $\mathrm{CaCO}_{3}$, calcium carbonate; NA, not applicable; - , no data; SMCL, Secondary Maximum Contaminant Level established by the U.S. Environmental Protection Agency (2012)]

\begin{tabular}{|c|c|c|c|c|c|c|c|c|c|}
\hline $\begin{array}{c}\text { Sample } \\
\text { Date }\end{array}$ & $\begin{array}{c}\text { Specific } \\
\text { conductance, } \\
\text { field }(\mu \mathrm{S} / \mathrm{cm} \\
\left.\text { at } 25^{\circ} \mathrm{C}\right)\end{array}$ & $\begin{array}{l}\text { Oxygen, } \\
\text { dissolved }\end{array}$ & $\begin{array}{l}\mathrm{pH}, \\
\text { field } \\
\text { (SU) }\end{array}$ & $\begin{array}{l}\text { Hardness } \\
\text { (as } \mathrm{CaCO}_{3} \text { ) }\end{array}$ & $\begin{array}{l}\text { Calcium, } \\
\text { filtered } \\
\text { (as Ca) }\end{array}$ & $\begin{array}{c}\text { Mag- } \\
\text { nesium, } \\
\text { filtered } \\
\text { (as } \mathrm{Mg} \text { ) }\end{array}$ & $\begin{array}{l}\text { Sodium, } \\
\text { filtered } \\
\text { (as Na) }\end{array}$ & $\begin{array}{c}\text { Chloride, } \\
\text { filtered } \\
\text { (as CI) }\end{array}$ & $\begin{array}{l}\text { Sulfate, } \\
\text { filtered } \\
\text { (as } \mathrm{SO}_{4} \text { ) }\end{array}$ \\
\hline \multicolumn{10}{|c|}{ Lake Claiborne, 1969-76 } \\
\hline $3 / 24 / 1969$ & 63 & - & 6.8 & 19 & 5.5 & 1.3 & 3.9 & 4.9 & 4.4 \\
\hline $9 / 15 / 1969$ & 67 & - & 7.0 & 19 & 6.4 & 0.7 & 4 & 4.5 & 2.6 \\
\hline $2 / 2 / 1970$ & 69 & - & 7.0 & 20 & 5.5 & 1.5 & 4 & 5.0 & 3.8 \\
\hline $7 / 12 / 1970$ & 57 & - & 6.3 & 16 & 5.2 & 0.7 & 3.2 & 4.0 & 4.4 \\
\hline $4 / 14 / 1976$ & 44 & 8.1 & 6.6 & 8 & 2.0 & 0.7 & 3.5 & 4.7 & 6.0 \\
\hline 7/14/1976 & 49 & 8.2 & 7.2 & 10 & 3.2 & 0.5 & 3.3 & 4.2 & 5.2 \\
\hline
\end{tabular}

\begin{tabular}{lllllllll}
\hline \multicolumn{10}{c}{ SMCLs } \\
\hline NA & NA & $6.5-8.5$ & NA & NA & NA & NA & 250 & 250 \\
\hline
\end{tabular}

${ }^{1}$ Station number 07364840 (U.S. Geological Survey, 2012c; specific data at http://nwis.waterdata.usgs.gov/la/nwis/qwdata/?site_no=07364840 


\section{Cited References}

Brantly, J.A., Seanor, R.C., and McCoy, K.L., 2002, Louisiana ground-water map no. 13-Hydrogeology and potentiometric surface, October 1996, of the Sparta aquifer in northern Louisiana: U.S. Geological Survey Water-Resources Investigations Report 02-4053, 3 sheets, accessed January 24, 2012, at http://pubs. er.usgs.gov/publication/wri024053.

Freiwald, D.A., and Johnson, S.F., 2008, Monitoring of Sparta aquifer recovery in southern Arkansas and northern Louisiana, 200307: U.S. Geological Survey Fact Sheet 2007-3102, 4 p, accessed August 9, 2012, at http://pubs.er.usgs.gov/publication/fs20073102.

Hem, J.D., 1985, Study and interpretation of the chemical characteristics of natural water ( $3 \mathrm{~d}$ ed.): U.S. Geological Survey Water-Supply Paper 2254, 264 p., accessed February 20, 2013, at http://pubs.er.usgs.gov/publication/wsp2254.

Hosman, R.L., 1978, Geohydrology of the northern Louisiana saltdome basin pertinent to the storage of radioactive wastes-A progress report: U.S. Geological Survey Water-Resources Investigations Report 78-104, 27 p.

Martin, J.L., Hough, L.W., Raggio, D.L., and Sandberg, A.E., 1954, Geology of Webster Parish: Louisiana Department of Conservation Geological Bulletin 29, 252 p.

Prakken, L.B., and Wright, L.S., 2009, Water withdrawals and trends in ground-water levels and stream discharge in Louisiana, 19962005: Louisiana Department of Transportation and Development Water Resources Technical Report no. 79, 49 p.

Ryals, G.N., 1984, Regional geohydrology of the northern Louisiana salt-dome basin, part II, geohydrologic maps of the Tertiary aquifers and related confining layers: U.S. Geological Survey Water-Resources Investigations Report 83-4135, 6 p.,7 pls., accessed May 15, 2012, at http://pubs.er.usgs.gov/publication/ wri834135.

Sargent, B.P., 2011, Water use in Louisiana, 2010: Louisiana Department of Transportation and Development Water Resources Special Report no. 17, 135 p.

Schrader, T.P., 2008, Potentiometric surface in the Sparta-Memphis aquifer of the Mississippi Embayment, spring 2007: U.S. Geological Survey Scientific Investigations Map 3014, 1 sheet, accessed August 9, 2012, at http://pubs.er.usgs.gov/publication/ $\operatorname{sim} 3014$.

Shampine, W.J., 1971, Chemical, biological, and physical data for the major lakes and reservoirs in Louisiana: Louisiana Department of Public Works Basin Records Report no. 5, 98 p.

Smoot, C.W., 1988, Louisiana hydrologic atlas map no. 3-Altitude of the base of freshwater in Louisiana: U.S. Geological Survey Water-Resources Investigations Report 86-4314, 1 sheet, accessed November 2, 2011, at http://pubs.er.usgs.gov/publication/wri864314.

Snead, J.I., and McCulloh, R.P., compilers, 1984, Geologic map of Louisiana: Louisiana Geological Survey, 1 sheet.

Stuart, C.G., Knochenmus, Darwin, and McGee, B.D., 1994, Guide to Louisiana's ground-water resources: U.S. Geological Survey WaterResources Investigations Report 94-4085, 55 p., accessed January 18, 2012, at http://pubs.er.usgs.gov/publication/wri944085.
Tomaszewski, D.J., Lovelace, J.K., and Ensminger, P.A., 2002, Water withdrawals and trends in ground-water levels and stream discharge in Louisiana: Louisiana Department of Transportation and Development Water Resources Technical Report no. 68, 30 p.

U.S. Environmental Protection Agency, 1992, Secondary Drinking Water Regulations - Guidance for nuisance chemicals: U.S. Environmental Protection Agency publication EPA 810/K-92001, 4 p., accessed July 29, 2009, at http://water.epa.gov/drink/ contaminants/secondarystandards.cfm.

U.S. Environmental Protection Agency, 2012, 2012 Edition of the drinking water standards and health advisories: U.S. Environmental Protection Agency publication EPA 822-S-12-001, Office of Water, 12 p., accessed August 7, 2012, at http://water.epa. gov/action/advisories/drinking/upload/dwstandards2012.pdf.

U.S. Geological Survey, 2012a, Groundwater levels for Louisiana [data for USGS 330002092445901 Cl- 149 Junction City]: National Water Information System Web Interface, accessed August 7, 2012, at http://nwis.waterdata.usgs.gov/la/nwis/gwlevel/?site_ no $=330002092445901$.

U.S. Geological Survey, 2012b, Water quality samples for Louisiana: National Water Information System Web Interface, accessed April 26, 2010, at http://nwis.waterdata.usgs.gov/la/nwis/qwdata/.

U.S. Geological Survey, 2012c, Water quality samples for Louisiana [data for USGS 07364840 Lake Claiborne near Aycock, LA]: National Water Information System Web Interface, accessed April 28, 2010, at http://nwis.waterdata.usgs.gov/la/nwis/qwdata/?site no $=07364840$.

This fact sheet was published by the U.S. Geological Survey, in cooperation with the Louisiana Department of Transportation and Development (DOTD). Thanks are given to Zahir "Bo" Bolourchi, Director, Water Resources Programs, Louisiana Department of Transportation and Development, who contributed to the content and design of the fact sheet.

\section{By Robert B. Fendick, Jr., Lawrence B. Prakken, and Jason M. Griffith}

\section{For additional information, contact:}

Director, USGS Louisiana Water Science Center

3535 S. Sherwood Forest Blvd., Suite 120

Baton Rouge, LA 70816

E-mail: dc_la@usgs.gov

Fax: (225) 298-5490

Telephone: (225) 298-5481

Home Page: http://la.water.usgs.gov 